\title{
OPTIMALISASI USAHATANI JAGUNG (Zea mays L.) DI KAMPUNG TUMBIT MELAYU KECAMATAN TELUK BAYUR KABUPATEN BERAU
}

\section{OPTIMIZATION OF CORN FARMING (Zea mays L.)IN TUMBIT MELAYU DISTRICT, BAYUR BAYUR DISTRICT, BERAU DISTRICT}

\author{
Indra Setiawan ${ }^{1}$, Sri Hartini ${ }^{2}$ \\ ${ }^{1,2}$ Program Studi Agribisnis Sekolah Tinggi Ilmu Pertanian (STIPER) Berau \\ Jl. Raja Alam I, Kelurahan Rinding, Kecamatan Teluk Bayur Kabupaten Berau, \\ Kalimantan Timur 77313, Indonesia \\ hartinihairudin@gmail.com
}

\begin{abstract}
ABSTRAK
Penelitian ini bertujuan untuk mengetahui tingkat produksi optimal usahatani jagung(Zea mays L.), besarnya penerimaan optimal, serta keuntungan optimal.Penelitian ini dilakukan di Kampung Tumbit Melayu Kecamatan Teluk Bayur Kabupaten Berau.Metode pengambilan responden yang digunakan dalam penelitian ini adalah Metode Sensus. Pengambilan data dilakukan dengan cara observasi ke lokasi penelitian dan mengadakan wawancara dengan responden. Petani responden ditentukan secara Sensus sebanyak 31 (tiga puluh satu) orang yang sebelumnya dikelompokkan terlebih dahulu dalam strata berdasarkan luas lahan. Analisis data yang digunakan adalah regresi kuadratik untuk persamaan biaya dan regresi linier untuk persamaan penerimaan. Hasil penelitian menunjukkan bahwa rata-rata produksi yang dicapai responden sebanyak $2.992 \mathrm{~kg} / \mathrm{ha}$ dengan keuntungan sebesar $\mathrm{Rp}$ 5.805.718,-/ha untuk satu kali panen. Dari hasil analisis diketahui persamaan biaya yaitu TC $=-3,07+865 Q-0,81 Q^{2}$ dan persamaan penerimaan yaitu $\mathrm{TR}=3.499 Q+0 Q^{2}$. Jumlah produksi pada tingkat penerimaan optimal sebesar $4.057 \mathrm{~kg}$. Besarnya penerimaan $\mathrm{Rp}$ 14.195.443,-/ha dan keuntungan optimal Rp 7.006.233,-/ha untuk satu kali musim tanam.
\end{abstract}

Kata kunci : Tingkat Produksi; Penerimaan Optoimal; Keuntungan Optimal

\section{ABSTRACT}

This study aims to determine the optimal level of production of corn farming (Zea mays L.), the optimal amount of acceptance, and optimal profits. This research was conducted in Kampung Tumbit Melayu, Teluk Bayur District, Berau Regency.The sampling method used in this study is the Census method. Data is collected by observation to the research location and conducting interviews with respondents. Respondent farmers were determined by Census as many as 31 (thirty one) people who were previously grouped first in strata based on land area. Analysis of the data used is quadratic regression for the cost equation and linear regression for the revenue equation.

The result of the research showed that the averange produc was $2.992 \mathrm{~kg}$ per hectare with profit as much $R p$ 5.805.718,- per hectare for one harvest. Than cost equition was TC= $-3,07+865 Q-0,81 Q^{2}$ revenue equition $T R=3.499 Q+0 Q^{2}$. The quantity of optimal production was $4.057 \mathrm{~kg}$. The revenue was $R p$ 14.195.443,-and optimal profit was $R p$ 7.006.233,- per hectare for one harvest.

Keywords: Production Level; Optimal Acceptance; Optimal Profit 


\section{Pendahuluan}

Tanaman pangan yang merupakan sektor penting, dan merupakan kelompok tanaman yang menghasilkan bahan pangan sebagai sumber energi untuk menopang kehidupan manusia. Sejak tahun 1960-an, pemerintah telah melaksanakan berbagai program inovatif untuk meningkatkan produksi dan produktivitas pertanian tanaman pangan yang dimulai dari program Demas SSBM (Demonstrasi Massal Swa Sembada Bahan Makanan) kemudian berkembang menjadi BIMAS (Bimbingan Masal) pada tahun 1967-1973, INMAS (Intensifikasi Masal), INMUM (Intensifikasi Umum), INSUS (Intensifikasi Khusus), SUPRA INSUS pada tahun 1987/1988, Intensifikasi Berwawasan Agribisnis (INBIS) dan pada tahun 2005 pemerintah meluncurkan program Revitalisasi Pertanian, Perikanan, dan Peternakan (RPPK). Saat ini Indonesia memprioritaskan tiga jenis tanaman pangan di Indonesia yaitu Padi, Jagung dan Kedelai (PAJALE) yang dilakukan melalui Upaya Khusus (Upsus) untuk meningkatan produksi pangan yang telah dilaksanakan sejak tahun 2015-2017 (Kementerian Pertanian 2018).

Salah satu subsektor pertanian yang masih menjadi prioritas pembangunan sektor pertanian adalah subsektor tanaman pangan adalah jagung.Jagung (Zea mays L) yang merupakan tanaman pangan strategis yang berkontribusi terhadap Produk Domestik Regional Bruto (PDRB) (Zubachtirodin dan Najmuddin 2005). Selain itu juga Jagung merupakan salah satu komoditas pangan sumber karbohidrat kedua setelah berasyang mempunyai peranan strategis dalam perekonomian nasional. Kedudukan sebagai sumber pangan utama mempunyai peluang yang cukup tinggi untuk dikembangkan sebagai bahan baku industry pengolahan pangan (Herlina \& Fitria, 2017).

Rumah tangga petani jagung merupakan yang terbesar kedua dengan jumlah 5.06 juta KK (7.57 persen) setelah rumahtangga petani padi sebesar 14.15 juta KK dan total keseluruhan rumahtangga petani tanaman pangan di Indonesia sebesar 17.83 juta KK, sehingga kondisi ini menggambarkan bahwa petani jagung masih memiliki peluang ekonomi dalam menjalankan usahatani yang lebih baik (Kementerian Pertanian, 2013).

Beberapa faktor penting yang perlu diperhatikan dalam upaya peningkatan produksi jagung diantaranya adalah penggunan input produksi yang optimum. Faktor-faktor tersebut saling berkaitan sehingga dalam peningkatan produksi jagung diperlukan pemahaman untuk mengelolanya agar bersinergis sehingga diperoleh hasil yang tinggi (Suwardi dan Roy, 2009).

Data yang diperoleh adalah hasil produksi jagung di Berau pada tahun 2014 mencapai 3.990 ton pipilan kering dari hasil Kaltim 7.567 ton pipilan kering. Pada tahun 2015 mencapai 4.555 ton pipilan kering dari hasil keseluruhan hasil Kaltim sebesar 8.379 ton pipilan kering. Pada tahun 2016 dari seluas 2.819 Hektar (Ha) lahan yang ada di Berau mampu menghasilkn sebanyak 15.460 ton dari produksi jagung Kaltim, yang mencapai 22.132 ton. Hal itu pun mengalami peningkatan di tahun 2017 dari luas lahan yakni 5.032 Ha dengan hasil panen mencapai 35.483 ton dari hasil produksi jagung Kaltim sebanyak 56.597 ton. Sedangkan di tahun 2018, dengan luas lahan $9.370 \mathrm{Ha}$, Berau mampu menghasilkan sebanyak 67.749 ton dari produksi jagung di Kaltim yang mampu menghasilkan sebanyak 88.105 ton atau meningkat 100 persen dalam setahun terakhir Pembangunan sektor pertanian di Kabupaten Berau memiliki potensi yang besar dan menjadi salah satu daerah yang diandalkan dalam memenuhi kebutuhan pangan di Kalimantan Timur maupun secara nasional. Salah satu produk pertanian yang diunggulkan adalah komoditas jagung yang saat ini memasok 76,89 persen dari total produksi jagung 
Kalimantan Timur sebesar 88.105 ton. (Dinas Pertanian dan Peternakan Kabupaten Berau, 2019).

Jagung adalah salah satu komoditas pangan unggulan yang ada di Kabupaten Berau selain Bawang Merah. Untuk Provinsi Kalimantan Timur, Pengembangan Jagung ditargetkan seluas 23 ribu Ha dan 12 ribu Ha yang ditanam di Kabupaten Berau. Jagung di Kampung Tumbit Melayu Kecamatan Teluk bayur memiliki potensi yg besar untuk di kembangkan karena luas lahan pertanian yang masih memadai untuk di tanami serta harga jagung pipilan kering di pasaran mencapai Rp 3.500-5.000 per $\mathrm{Kg}$, sedangkan jagung basah di hargai $\mathrm{Rp}$ 3.000-3.500 per kilo gramnya. Dengan harga saat ini tersebut di harapkan petani akan tetap bergairah menanam jagung. Di Kabupaten Berau khususnya di Kecamatan Teluk Bayur mengalami peningkatan luas panen mulai pada tahun 2016-2018 berkisar $66 \mathrm{Ha}$ - $178 \mathrm{Ha}$.(Dinas Pertanian dan Peternakan Kabupaten Berau, 2019).

\section{Metode Penelitian}

Penelitian ini menggunakan metode sensus yaitu dengan menggunakan seluruh petani jagung yaitu 31 orang responden yang menamam jagung pada saat melakukan penelitian di Kampung Tumbit Melayu Kecamatan Teluk Bayur Kabupaten Berau yang memulai panennya pada bulan Januari-September 2019.Data yang digunakan dalam penelitian ini adalah data primer dan data sekunder.Data primer diperoleh dengan cara observasi langsung ke lokasi penelitian dan mengadakan wawancara langsung dengan responden menggunakan daftar pertanyaan yang telah disusun sesuai dengan tujuan penelitian. Data sekunder diperlukan untuk menunjang data primer diperoleh dari studi kepustakaan, lembaga-lembaga yang terkait, petugas penyuluh lapangan (PPL) setempat dan instansi-instansi terkait yaitu Dinas Pertanian dan Peternakan Kabupaten Berau.

\section{Analisis Data}

Analisis Data dalam penelitian ini sebagaimana disampaikan Boediono (2002), untuk mengetahui jumlah biaya yang dikeluarkan dalam suatu usahatani untuk mengetahui tingkat produksi optimal, dapat dilakukan dengan menggunakan pendekatan persamaan antara biaya keseluruhan dengan jumlah produksi, yaitu:

$$
\begin{gathered}
C=f(Q) \\
C=a+b Q+c Q^{2}
\end{gathered}
$$

Keterangan :

$$
\begin{array}{ll}
\mathrm{C} & =\text { Biaya }(\text { cost }) \\
\mathrm{a} & =\text { Koefisien biaya tetap/konstanta } \\
\mathrm{b}, \mathrm{c} & =\text { Koefisien biaya tidak tetap } \\
\mathrm{Q} & =\text { Jumlah produksi (quantity) }
\end{array}
$$

Persamaan biaya tersebut dapat diselesaikan dengan menggunakan persamaan kuadratik:

$$
C=a+b Q+c Q^{2}
$$

$$
\begin{aligned}
& \text { Maka }: \sum C=n a+b \sum Q+c \sum Q^{2} \\
& \sum C=a \sum Q+b \sum Q^{2}+c \sum Q^{3} \\
& \sum C=a \sum Q^{2}+b \sum Q^{3}+c \sum Q^{4}
\end{aligned}
$$

Sudjana (1992) Nilai a, b, dan c dapat diperoleh dengan menggunakan rumus determinasi :

$$
\left[\begin{array}{ccc}
n & \sum Q & \sum Q^{2} \\
\sum Q & \sum Q^{2} & \sum Q^{3} \\
\sum Q^{2} & \sum Q^{3} & \sum Q^{4}
\end{array}\right]\left[\begin{array}{l}
a \\
b \\
c
\end{array}\right]=\left[\begin{array}{c}
\sum C \\
\sum C Q \\
\sum C Q^{2}
\end{array}\right]
$$

Wasis (1981) menyatakan besarnya penerimaan (Revenue) untuk mengetahui besarnya penerimaan optimal, dapat ditentukan dengan pendekatan persamaan:

$$
\begin{array}{r}
P=f(Q) \\
P=a+b Q \\
T R=P \times Q \\
\text { Maka : TR }=(\mathrm{a}+\mathrm{bQ}) \times \mathrm{Q} \\
T R=a Q+b Q^{2}
\end{array}
$$

Keterangan :

$\mathrm{TR}=$ Total penerimaan (total revenue)

$\mathrm{P} \quad=$ Harga (price)

$\mathrm{Q} \quad=$ Jumlah produksi (quantity)

$\mathrm{a}, \mathrm{b}=$ Konstanta, koefisien arah 
Maka $: P=n a+b \sum Q$

$$
P Q=a \sum Q+b \sum Q^{2}
$$

Sudjana (1992) untuk mengetahui nilai a dan $b$ menurut dapat dicari dengan menggunakan rumus sebagai berikut :

$$
\begin{gathered}
a=\frac{\sum p \sum Q^{2}-\sum Q \sum P Q}{n \sum Q^{2}-\left(\sum Q\right)^{2}} \\
b=\frac{n \sum P Q-\sum P \sum Q}{n \sum Q^{2}-\left(\sum Q\right)^{2}}
\end{gathered}
$$

Selanjutnya menurut Gespersz (2001), untuk menentukan tingkat produksi optimal maka biaya tambahan (MC) sama dengan tambahan penerimaan (MR) dapat dicapai pada saat :

$$
\begin{aligned}
& M C=M R \\
& \frac{d C}{d Q}=\frac{d R}{d Q}
\end{aligned}
$$

Keterangan :

MC = Tambahan biaya (Marginal Cost $)$

MR = Tambahan peneriman (Marginal

$$
\text { Revenue) }
$$

$\frac{d C}{d Q}=$ Turunan pertama persamaan biaya

$\frac{d R}{d Q}=$ Turunan pertama persamaan

penerimaan

Sedangkan untuk mengetahui besarnya keuntungan optimal pada produksi optimal adalah :

$$
\pi \operatorname{Max}=T R-T C
$$

Keterangan :

$$
\begin{array}{ll}
\pi \text { Max }= & \begin{array}{l}
\text { Keuntungan tertinggi } \\
\text { (Maximum Profit })
\end{array} \\
\mathrm{TR} & =\begin{array}{l}
\text { Total penerimaan } \\
\text { Revenue })
\end{array} \\
\mathrm{TC} & =
\end{array}
$$

\section{Hasil Dan Pembahasan}

Kampung Tumbit Melayu terletak di dalam wilayah Kecamatan Teluk Bayur Kabupaten Berau berbatasan dengan :Kampung Bena Baru Sebelah Utara,
Kampung Tumbit Dayak Sebelah Timur, Kampung Tumbit Dayak Sebelah Selatan dan Kampung Labanan Makmur Sebelah Barat. Luas wilayah Kampung Tumbit Melayu adalah $7865 \mathrm{Ha}$ dimana 65\% berupa daratan yang bertopografi berbukitbukit, dan $35 \%$ daratan dimanfaatkan sebagai lahan pertanian/perkebuanan yang dimanfaatkan untuk persawahan tadah hujan dan perkebunan. Iklim Kampung Tumbit Melayu, sebagaimana kampung lain di wilayah Indonesia mempunyai iklim Kemarau dan Penghujan, hal tersebut mempunyai pengaruh langsung terhadap pola tanam pada lahan pertanian yang ada di Kampung Tumbit Melayu Kecamatan Teluk Bayur (Badan Pusat Statistik, 2018).

Berdasarkan hasil penelitian pada usahatani jagung di kampung Tumbit Melayu serta hasil pengamatan langsung di lokasi penelitian, maka diperoleh gambaran karakteristik responden sebagai berikut:

\section{Umur Responden}

Hasil pengolahan data menunjukkan bahwa umur responden dalam penelitian ini, berkisar antara 40 sampai 76 tahun. Faktor umur akan mempengaruhi aktivitas kerja para petani dalam menjalankan usahataninya. Petani yang memiliki umur relatif muda akan menunjukkan kerja yang lebih produktif karena memiliki kemampuan yang lebih besar dalam mengelola usahataninya.

Tabel 1. Klasifikasi Responden berdasarkan Kelompok Umur di kampung Tumbit Melayu (Data Hasil Penelitian diolah 2019)

\begin{tabular}{cccc}
\hline No & $\begin{array}{c}\text { Kelompok } \\
\text { Umur } \\
\text { (tahun) }\end{array}$ & $\begin{array}{c}\text { Jumlah } \\
\text { (jiwa) }\end{array}$ & $\begin{array}{c}\text { Persentase } \\
(\boldsymbol{\%})\end{array}$ \\
\hline 1 & $15-64$ & 26 & 84 \\
2 & $\geq 65$ & 5 & 16 \\
\hline & Jumlah & $\mathbf{3 1}$ & $\mathbf{1 0 0}$ \\
\hline
\end{tabular}


Pada Tabel 1. dapat diketahui bahwa responden sebagian besar berada pada usia produktif dengan jumlah yaitu (84\%) terdapat pada umur 15 sampai 64 tahun, dimana umur berpengaruh terhadap produktivitas kerja, dimana umur yang produktif menyebabkan produktivitas tenaga kerja semakin meningkat (Herawati dan Sasana, 2013).Bahwa orang yang lebih muda menjadi yang lebih produktif, karena mereka lebih semangat atau dapat bekerja lebih keras.

\section{Pendidikan Responden}

Pendidikan mempunyai peranan yang penting bagi para petani dalam melakukan kegiatan usahataninya.Pendidikan disini tidak hanya yang formal saja tetapi juga informal. Dengan pendidikan dan pengetahuan yang tinggi, petani akan mampu menyerap teknologi pertanian yang semakin berkembang dalam usahanya untuk meningkatkan hasil usahatani yang diupayakannya. Pendidikan dan pengetahuan yang tinggi tidak akan berarti tanpa didukung dengan motivasi, kemauan dan pola pikir yang semakin berkembang pula.

Tabel 2 : Klasifikasi Responden berdasarkan Tingkat Pendidikan Formal ( Data Hasil Penelitian diolah 2019)

\begin{tabular}{cccc}
\hline No & $\begin{array}{c}\text { Jumlah } \\
\text { Tanggungan }\end{array}$ & $\begin{array}{c}\text { Jumlah Persentase } \\
\text { (jiwa) }\end{array}$ & \begin{tabular}{c}
$(\boldsymbol{\%})$ \\
\hline 1
\end{tabular} \\
$\mathbf{1 - 2}$ & 17 & 54,84 \\
2 & $\mathbf{3 - 4}$ & 13 & 41,94 \\
3 & $\mathbf{5 - 6}$ & 1 & 3,23 \\
\hline & Jumlah & $\mathbf{3 1}$ & $\mathbf{1 0 0}$ \\
\hline
\end{tabular}

Pada Tabel 2. menunjukkan tingkat pendidikan terbanyak adalah tamatan Sekolah Dasar (SD) yaitu sebanyak 15 jiwa dengan persentase sebesar 48,39\%, sedangkan untuk tamatan SMP sebesar 38,71 \% dan tamatan SMA sebesar $12,90 \%$. Hal ini memberikan gambaran bahwa rata-rata petani masih berpendidikan relatif rendah, sehingga perlu diadakan tambahan penyuluhan guna meningkatkan pengetahuan dan keterampilan petani dalam hal memperkenalkan teknologi pertanian yang semakin maju dan modern. Namun Pendidikan Tidak Berpengaruh Secara Signifikan Terhadap Produktivitas Tenaga Kerja. Hal Ini Dapat Diartikan Bahwa Tinggi Rendahnya Pendidikan Tidak Mempengaruhi Tinggi Rendahnya Produktivtas Tenaga Kerja (Herawati dan Sasana, 2013).

\section{Tanggungan Keluarga}

Tabungan Keluarga merupakan salah satu faktor yang mempengaruhi keputusan dalam melakukan suatu kegiatan usahatani. Semakin banyak anggota keluarga yang ditanggung, maka akan semakin besar pula tuntutan untuk memenuhi kebutuhan keluarga. Dalam hal ini para petani sebagai kepala keluarga selalu berupaya untuk meningkatkan pendapatan keluarga.Tanggungan keluarga meliputi istri, anak dan anggota keluarga lain yang ikut serta menjadi tanggungan petani responden tersebut. Jumlah tanggungan keluarga responden dapat dilihat pada Tabel 3.

Tabel 3 : Klasifikasi Responden berdasarkan Tanggungan Keluarga(Data Penelitian diolah, 2019)

\begin{tabular}{|c|c|c|c|}
\hline No & $\begin{array}{c}\text { Tingkat } \\
\text { Pendidikan }\end{array}$ & $\begin{array}{c}\text { Jumlah } \\
\text { (jiwa) }\end{array}$ & $\begin{array}{c}\text { Persentase } \\
(\%)\end{array}$ \\
\hline $\begin{array}{l}1 \\
2 \\
3\end{array}$ & $\begin{array}{c}\text { Tamat SD/ } \\
\text { sederajat } \\
\text { Tamat SLTP/ } \\
\text { sederajat } \\
\text { Tamat SLTA/ } \\
\text { sederajat } \\
\end{array}$ & $\begin{array}{c}15 \\
12 \\
4\end{array}$ & $\begin{array}{l}48,39 \\
38,71 \\
12,90\end{array}$ \\
\hline & Jumlah & 31 & 100 \\
\hline & $\begin{array}{l}\text { Berdasarkan } \\
\text { ahui bahwa } \\
\text { rga berkisar an } \\
\text { amlah tanggun } \\
\text { ada interval } 1 \text { - }\end{array}$ & $\begin{array}{l}\text { tabel } \\
\text { jumlah } \\
\text { tara } 2 \text { sa } \\
\text { an kelua }\end{array}$ & $\begin{array}{l}\text { 3. dapat } \\
\text { tanggungan } \\
\text { npai } 6 \text { orang } \\
\text { ga terbanyak } \\
\text { itu sebanvak }\end{array}$ \\
\hline
\end{tabular}




\section{Luas Lahan Responden}

Luas lahan yang dimilki oleh 31 responden di Kampung Tumbit Melayu Kecamatan Teluk Bayur yang digunakan untuk usahatani jagung berkisar antara 0,25 sampai 2 ha dengan luas rata-rata 0,81 ha. Lahan Jagung terluas dimiliki sebanyak 41,94\% responden.

Tabel 4. Klasifikasi Responden berdasarkan Luas Lahan( Data Hasil Penelitian diolah 2019)

\begin{tabular}{cccc}
\hline No & $\begin{array}{c}\text { Luas Lahan } \\
\text { (ha) }\end{array}$ & $\begin{array}{c}\text { Jumlah } \\
\text { (jiwa) }\end{array}$ & $\begin{array}{c}\text { Persentase } \\
(\boldsymbol{\%})\end{array}$ \\
\hline 1 & $\leq 0,50$ & 13 & 41,94 \\
2 & $>0,50-1,49$ & 5 & 16,13 \\
3 & $\geq 1,50-2,00$ & 13 & 41,94 \\
\hline Jumlah & 31 & 100 \\
\hline
\end{tabular}

Usahatani Jagung pada saat penelitian sebagai berikut :Usahatani Jagung (Zea mays L.) dilakukan sebanyak dua kali dalam setahun yaitu pada bulan Februari dan bulan September dengan sistem budidaya sebagai berikut :

Persiapan Lahan :Penyiapan lahan yang dilakukan petani jagung pada lahan kering diawali dengan melakukan penyiapan lahan dengan membersihkan dan mengolah lahan terlebih dahulu menggunakan traktor dan cangkul untuk lahan yang cukup datar.

Penanaman :Penanaman yang dilakukan petani jagung pada lahan kering umumnya dilakukan setelah lahan dibajak tanpa membuat lubang tanam sedangkan pada lahan yang miring dibuat lubang terlebih dahulu dengan cara ditugal (asak). Benih jagung yang ditanam pada lahan kering untuk varietas unggul lama yaitu sygenta NK212 dan Bisi 18. Rata-rata jarak tanam yang digunakan oleh petani jagung pada lahan kering cukup beragam yaitu $70 \mathrm{~cm} \mathrm{x}$ $20 \mathrm{~cm}$ dan $70 \mathrm{~cm} \times 45 \mathrm{~cm}$ dan antar baris bedengan dibuat jarak $100 \mathrm{~cm}$, dengan pengisian benih sebanyak 2-3 biji benih jagung per lubang. Adapun sistem tanam jajar legowo yang digunakan petani dengan lebar bedengan $50 \mathrm{~cm}$ dan jarak antar bedengan \pm 1 meter.Jarak tanam yang sesuai anjuran $70 \mathrm{~cm} \times 20 \mathrm{~cm}$ untuk 1 biji per lubang.Akan tetapi, petani tidak menggunakan sesuai anjuran karena resiko benih jagung tidak tumbuh dengan baik.

Pemupukan :Pemupukan yang pada umumnya dilakukan petani sebanyak dua kali. Pemupukan pertama dilakukan setelah dua minggu penanaman pada kisaran umur jagung 15-20 hari setelah tanam (HST).Kemudian pemupukan kedua dilakukan setelah umur jagung setelah dua bulan pada kisaran umur jagung 40-45 HST.Jenis pupuk yang digunakan peetani jagung adalah pupuk Urea, pupuk Phonska (NPK).Pupuk pertama ditabur atau ditanam di kanan dan kiri lubang tanam, pemupukan kedua ditanam mengitari tanaman dengan jarak kira-kira (sesuai perkiraan petani).Pupuk pertama diberikan dengan dosis $1 / 3$ pupuk Urea serta $2 / 3$ pupuk Phonska.Aplikasi dosis pupuk yang direkomendasikan adalah tiga tahap, yaitu tahap pemberiaan pupuk dasar (PD), tahap susulan I (S I) dan tahap susulan II (S II). Dosis yang diberikan pertanahnya adalah 1/3 dari pupuk Urea, Phonska dengan waktu pemberian bersamaan dengan penanaman (PD), 40-45 hari setelah tanam (S II) dan waktu jagung mulai berbuah atau mulai tumbuh malai (S II). Adapun kegiatan pemupukan dilakukan oleh lakilaki dan perempuan.

Pemeliharaan :Pemeliharaan umumnya di daerah penelitian dilakukan dengan melakukan pembersihan gulma dengan menggunakan Purba, Edison (2011)mengemukakan bahwa kehilangan hasil akibatgulma rata-rata $10 \%(15 \%$ di daerah tropis) dangulma umum menurunkan hasil sampai $31 \%$ pada tanaman jagung. Oleh sebab itu petani melakukan penyemprotan sebanyak dua kali yaitu sebelum pemupukan pertama dan sebelum pemupukan kedua. Ini tujuannya untuk meningkatkan hasil produksi tanaman Jagung. Kegiatan penyemprotan gulma dengan pemberian 
berbagai dosisherbisida memberikan pengaruh tidak berbedanyata terhadap komponen pertumbuhan, komponen hasil, dan hasil tanaman. Perlakuan dengandosis herbisida terendah yaitu 0,75 L/ha memberikan respon dan hasil yang sama dibandingkandengan perlakuan penyiangan manual (Wahyudin et al, 2016). Hal ini sangat berdampak terhadap pengeluaran penghematan biaya tenaga kerja dan tenaga kerja digunakan adalah lakilaki.Untuk Tanaman JagungSerangan hama umumnya tidak dijumpai

Panen :Panen jagung dilakukan pada saat berumur 110-120 HST. Pemanenan usahatani jagung pada lahan kering umumnya dilakukan dengan membayar tenaga kerja laki-laki dan perempuan secara harian dengan upah kisaran $\mathrm{Rp}$ 80.000 ,- sampai Rp 100.000,- per hari kerja.

Pascapanen :Pascapanen meliputi kegiatan pemipilan jagung dan pengeringan jagung. Pemipilan jagung dengan menggunakan mesin penggiling jagung.Penggilingan jagung dilakukan di lahan usahatani jagung.Kegiatan pengeringan jagung dilakukan jika petani mau menjual jagungnya dalam keadaan kering biasanya dilakukan pengeringan selama 1 minggu.Akan tetapi sebagian besar petani menjual jagung dalam keadaan basah.Petani menjual jagung pada pedagang pengumpul yang ada di kampung.Sistemnya pedagang langsung yang mendatangi petani dan menyiapkan mesin pemipil, tenaga kerja pemipil dan karung serta tali ikat karung. Harga jual jagung petani pada daerah penelitian berkisar sebesar Rp 3.000,- sampai Rp 5.000,- pada keadaan jagung basah maupun jagung kering.

Biaya Produksi :Biaya produksi adalah nilai dari semua faktor produksi yang digunakan dalam kegiatan usahatani. Dalam penelitian ini, biaya produksi yang diperhitungkan dalam usahatani Jagung terdiri dari biaya variabel yaitu biaya sarana produksi untuk benih, pupuk, pestisida dan biaya tenaga kerja, sedangkan biaya tetap adalah biaya penyusutan alat.

Biaya Sarana Produksi :Biaya sarana produksi terdiri dari biaya benih, pupuk dan pestisida. Benih yang digunakan oleh petani responden di Kampung Tumbit Melayu adalah sygenta NK212 dan Bisi 18.Harga rata-rata benih tersebut adalah sebesar Rp 15.000,-/kg. Banyaknya benih Jagung yang digunakan oleh 31 petani responden adalah $336 \mathrm{~kg} / \mathrm{MT}$ dengan ratarata sebesar 10,84 kg/MT untuk luas lahan 0,81 ha, sehingga jumlah biaya yang dikeluarkan oleh 31 petani responden adalah sebesarRp 5.145.000,-/MT dengan rata-rata $\mathrm{Rp} 165.968,-/ \mathrm{MT}$ untuk luas lahan 0,81 ha atau rata-rata $\mathrm{Rp} 331.935$,/Thn.

Pupuk yang digunakan oleh petani responden adalah pupuk Urea, dan pupuk Ponska.Semua responden menggunakan pupuk dalam kegiatan usahataninya, tetapi ada yang hanya menggunakan satu macam pupuk saja, hal ini dikarenakan ketidakmampuan petani dalam membeli pupuk tersebut.Adapun jumlah petani responden yang menggunakan pupuk sebanyak 31 reponden. Menggunakan pupuk Urea ada 7 responden, sedangkan menggunakan pupuk Ponska 11 responden, dan yang memakai keduanya ada 13 responden..

Harga pupuk Urea rata-rata yang digunakan di lokasi penelitian adalah sebesar Rp 1.900,-/kg, pupuk Ponska rata-

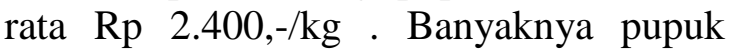
Urea yang digunakan oleh 7 responden adalah $650 \mathrm{~kg} / \mathrm{MT}$ dengan rata-rata sebesar 92,86 kg/MT pada luas lahan 0,81 ha. Penggunaan pupuk Ponska oleh 11 responden adalah sebanyak $1.300 \mathrm{~kg} / \mathrm{MT}$ dengan rata-rata penggunaan sebesar $185,71 \mathrm{~kg} / \mathrm{MT}$ untuk luas lahan 0,81 ha.

Adapun total biaya keseluruhan untuk penggunaan pupuk oleh 31 
responden adalah sebesar $\mathrm{Rp}$ 10.285.000,/MT dengan rata-rata sebesarRp 331.774,-/MT pada luas lahan 0,81 ha atau rata-rata Rp 663.548,-/Thn.

Pestisida yang digunakan oleh petani responden adalah jenis Kayabas dan Calaris. Penggunaan pestisida ini tergantung pada kemampuan petani responden dalam pembelian dan tingkat serangan gulma dan hama. Jumlah biaya pestisida yang dikeluarkan oleh 31 responden adalah sebesar Rp7.230.000,/MT dengan rata-rata sebesar Rp 233.226,/MT pada luas lahan 0,81 ha atau ratarataRp 446.452,-/Thn.

Biaya Tenaga Kerja :Biaya tenaga kerja yang diperhitungkan adalah biaya persiapan lahan, biaya pembibitan, biaya penanaman, biaya pemeliharaan (pemupukan, pengendalian hama dan penyiangan), biaya panen dan biaya pasca panen.

Jumlah HOK untuk 31 responden pada pengolahan lahan adalah sebesar 45,00 HOK/MT dengan rata-rata 1,45 HOK/MT pada luas lahan 0,81 ha. Pada Lampiran 6, diketahui bahwa jumlah HOK untuk pengolahan lahan dengan menggunakan hand tractor.

Jumlah HOK pemeliharaan dari 31 responden adalah sebesar 34,00 HOK/MT Pria atau rata-rata 1,10 HOK/MT Pria dan sebesar 12,00 HOK/MT Wanita atau ratarata $0,39 \mathrm{HOK} / \mathrm{MT}$ Wanita pada luas lahan 0,81 ha. Diketahui bahwa jumlah HOK pemeliharaan untuk setiap responden berbeda-beda.Nilai HOK yang kecil disebabkan adanya petani responden yang hanya memberi satu jenis pupuk saja pupuk pada usahataninya.

Pada kegiatan pembibitan, penanaman, pemanenan dan pasca panen nilai HOK untuk masing-masing petani responden tidak terlalu jauh berbeda, karena cara dan teknik yang dilakukan petani tersebut sama. Biaya tenaga kerja dihitung dalam pendapatan usahatani dan dinilai sesuai standar upah tenaga kerja yang berlaku di lokasi penelitian yaitu sebesar Rp 80.000,-/HOK Wanita dan Rp 100.000,-/HOK Pria.

Jumlah keseluruhan HOK usahatani Jagung di lokasi penelitian dari 31 responden adalah sebesar 177,00 HOK/MT Pria dengan rata-rata 5,71 HOK/MT Pria dan sebesar 73,00 HOK/MT Wanita dengan rata-rata 2,35 HOK/MT Wanita pada luas lahan 0,81 ha. Total biaya tenaga kerja yang dikeluarkan oleh 31 reponden adalah Rp 23.540.000,/MT dengan rata-rata sebesar Rp 759.355,/MT pada luas lahan 0,81 ha atau rata-rata Rp 1.158.710,-/Thn.

Biaya Sewa Alat:Biaya sewa alat yang dikeluarkan adalah biaya sewa hand tractor. Biaya sewa alat yang dikeluarkan oleh 31 responden adalah sebesar $\mathrm{Rp}$ 11.625.000,-/MT dengan rata-rata sebesar Rp 375.000,-/MT pada luas lahan 0,81 ha atau sebesar Rp 750.000,-/Thn.

Biaya Penyusutan Alat:Biaya penyusutan alat yang dikeluarkan adalah penyusutan alat-alat pertanian meliputi cangkul, arit, parang dan hand sprayer. Biaya penyusutan alat-alat pertanian tersebut diperoleh dengan cara menghitung harga pembelian di kurang dengan nilai sisa sebesar Rp 10.000,- dikalikan dengan jumlah barang lalu dibagi dengan umur teknis alat yang bersangkutan selama 1 kali proses produksi (1 MT) yaitu 4 bulan.

Biaya penyusutan yang dikeluarkan oleh 31 responden adalah sebesarRp 4.398.333,-/MT dengan rata-rata sebesar Rp 141.882,-/MT pada luas lahan 0,81 ha atau sebesar Rp 283.763,-/Thn.

Jumlah biaya produksi secara keseluruhan dari 31 responden pada usahatani Jagung di Kampung Tumbit Melayu dengan total luasan lahan 25 ha, meliputi biaya sarana produksi, tenaga kerja, sewa alat dan penyusutan alat adalah sebesar Rp 124.447.667,-/Thn. Pada luas lahan 0,81 ha atau rata-rata 4.014.409,/Tahun. 


\section{Produksi dan Penerimaan Usahatani Jagung.}

Produksi adalah hasil yang diperoleh dalam satu kali musim tanam berupa pipilan kering, sedangkan jumlah produksi dikalikan dengan harga jual akan diperoleh hasil penerimaan petani responden.

Berdasarkan hasil penelitian terhadap 31 responden usahatani jagung di Kampung Tumbit Melayu diperoleh produksi sebesar $75.750 \mathrm{~kg} / \mathrm{MT}$ pada luas lahan 25 ha dengan rata-rata sebesar 2.444 $\mathrm{kg} / \mathrm{MT}$ pada luas lahan 0,81 ha atau 4.887 $\mathrm{kg} / \mathrm{Thn}$. Diketahui bahwa responden yang menggunakan sistem pengolahan lahan (hand tractor) memiliki jumlah produksi yang tidak jauh berbeda dengan usahatani Tanpa Olah Tanah (TOT). Hal ini menunjukkan bahwa pengolahan lahan tidak berpengaruh besar pada jumlah produksi.Perbedaan jumlah produksi yang dihasilkan masing-masing responden dipengaruhi faktor pemupukan. Pada Lampiran 4 diketahui bahwa responden ada yang memberikan dua jenis pupuk pada usahataninya akan memperoleh jumlah produksi yang tinggi dibandingkan dengan usahatani yang menberikansatu jenis pupuk saja.

Harga jual rata-rata adalah $\mathrm{Rp}$ $3.500,-/ \mathrm{kg}$, dan dengan penjualan hasil produksi tersebut diperoleh penerimaan total oleh 31 responden sebesar Rp 265.125.000,-/MT dengan rata-rata $\mathrm{Rp}$ 8.552.419,-/MT pada luas lahan 0,81 ha atau Rp 17.104839,-/Thn. Besar kecilnya penerimaan tersebut dipengaruhi oleh jumlah produksi, Responden yang memiliki produksi tinggi dan dapat menjual dengan harga tinggi akan mendapatkan penerimaan yang besar dan berlaku sebaliknya untuk jumlah produksi yang sama apabila dijual dengan harga rendah maka penerimaan yang diterima akan kecil.

\section{Pendapatan dan R/C Ratio Usahatani Jagung}

Pendapatan petani responden
diperoleh dari selisih antara total
penerimaan dengan total biaya yang telah
dikeluarkan dalam satu kali musim tanam.
Jumlah pendapatan dari 31 responden adalah
sebesar Rp 405.803.333,-/Thn dengan rata-
rata Rp 13.090.430,-/Thn pada luas lahan
0,81 ha.

$\mathrm{R} / \mathrm{C}$ ratio adalah perbandingan antara total penerimaan dengan total biaya, maka dapat diketahui bahwa besarnya R/C ratio rata-rata adalah sebesar 4,11 setiap responden. Hal tersebut dapat diartikan bahwa untuk setiap Rp 1.000,- yang dikeluarkan pada awal kegiatan usahatani akan diperoleh penerimaan sebesar Rp 4.110,- pada akhir kegiatan usahatani. Dari hasil tersebut dapat dikatakan bahwa petani responden di lokasi penelitian telah memperoleh keuntungan dalam melaksanakan kegiatan usahataninya. Semakin besar $\mathrm{R} / \mathrm{C}$ ratio maka akan semakin besar pula keuntungan yang diperoleh petani. Hal ini dapat dicapai bila petani mengalokasikan faktor produksi dengan lebih efisien.

\section{Analisis Hasil Usahatani Jagung}

Tingkat produksi optimal syaratnya adalah turunan pertama persamaan biaya sama dengan turunan pertama persamaan penerimaan $\mathrm{MC}=\mathrm{MR}$. Berdasarkan hasil penelitian diperoleh bahwa tingkat produksi optimal pada usahatani jagung adalah sebesar $4.057 \mathrm{~kg}$, sehingga diperoleh penerimaan optimal sebesar Rp 14.195.443,-.dan diperoleh tingkat produksi optimal $4.057 \mathrm{~kg} / \mathrm{ha}$ dalam satu kali musim tanam.

\section{Persamaan jumlah biaya (total cost) dan persamaan jumlah penerimaan (total revenue)}

Berdasarkan hasil analisis data penelitian diperoleh persamaan biaya (TC) dengan menggunakandeterminasi melalui 
hubungan antara biaya dan produk, dimana

$$
T C=a+b Q+c Q^{2}
$$

Maka : TC $=-3,07+865 Q-0,81 Q^{2}$

Sedangkan Persamaan penerimaan (TR) diperoleh dengan menggunakan persamaan regresi linier melalui hubungan antara harga dengan produk, dimana:

$$
\begin{gathered}
\text { TR }=a Q+b Q^{2} \\
\text { Maka }: \mathrm{TR}=3.499 Q+0 Q^{2}
\end{gathered}
$$

Pada tingkat produksi tersebut diperoleh penerimaan sebesar $\mathrm{Rp}$ 14.195.443,-/ha dengan biaya produksi sebesar Rp 7.189.210,-/ha, maka keuntungan yang diperoleh sebesar $\mathrm{Rp}$ 7.006.233,-/ha.

\section{Keuntungan optimal pada tingkat produksi optimal dengan syaratnya} adalah total penerimaan dikurangi total biaya produksi atau $\pi=\mathrm{TR}-\mathrm{TC}$ yaitu TR sebesar Rp 14.195.443,- dikurangi TC sebesar Rp 7.189.210,- sehingga diketahui bahwa besarnya keuntungan optimal pada tingkat produksi optimal $4.057 \mathrm{~kg}$ adalah sebesar Rp 7.006.233,-/ha dalam satu kali musim tanam yang merupakan keuntungan tertinggi dalam kegiatan usahatani. Tetapi bila dibandingkan dengan produksi yang berhasil dicapai rata-rata responden sebesar $2.992 \mathrm{~kg} / \mathrm{ha}$, dengan penerimaan yang diperoleh sebesar Rp 10.468.813,-/ha dan biaya produksi sebesar Rp 4.663.095,-/ha sehingga diperoleh keuntungan sebesar Rp 5.805.718,-/ha.

Tingkat produksi, penerimaan, keuntungan akan tercapai bila penggunaan faktor-faktor produksi telah efisien dan harga yang berlaku dapat menjamin keadaan tersebut, sehingga produksi yang diperoleh mencerminkan tingkat efisiensi dari usahatani (Ahyari, 1981). Namun pada umumnya petani lebih biasa mengukur tingkat efisiensi produksi dari besarnya hasil dan tidak dari rendahnya biaya yang dikeluarkan untuk memproduksi hasil tersebut (Mubyarto, 1995).
Hasil produksi yang rendah ini disebabkan oleh kurangnya pengetahuan petani mengenai teknik bercocok tanam. Hal ini dapat dilihat dari penggunaan benih yang berlebihan, belum melakukan pemupukan yang seimbang, kemudian ada beberapa responden yang tidak melakukan pengendalian hama, penyakit dan jasad pengganggu lainnya menggunakan pestisida.

Untuk mengatasi keadaan tersebut, maka diperlukan peningkatan frekuensi penyuluhan teknik budidaya kepada petani sehingga dapat menggunkan sarana produksi secara tepat.Frekuensi penyuluhan yang lebih banyak kepada petani tentang budidaya maka usahatani diharapkan dapat mencapai keuntungan yang optimal.

Dalam teori ekonomi, diambil asumsi dasar mengenai sifat dan fungsi produksi, yaitu "The Law of Deminishing Returns". Dimana hukum ini menyatakan bila satu macam input ditambah terus menerus sedang input lain dianggap tetap maka tambahan output yang dihasilkan dari setiap tambahan satu unit tersebut mula-mula menaik dan setelah mencapai maksimal kemudian menurun.

Tidak tercapainya keuntungan yang optimal/maksimal ini karena beberapa hal seperti kecilnya modal yang dikeluarkan petani dan pengelolaan usahatani, menyebabkan pengolahannya yang kurang baik.Besar kecilnya keuntungan yang diperoleh sangat tergantung dari besar kecilnya modal yang digunakan serta baik buruknya pengelolaan.

\section{Kesimpulan}

Total produksi yang dicapai oleh 31 responden adalah sebanyak $75.750 \mathrm{~kg} / \mathrm{MT}$ dengan rata-rata $2,444 \mathrm{~kg} / \mathrm{MT}$ untuk ratarata luas lahan 0,81 atau $2.992 \mathrm{~kg} / \mathrm{ha} / \mathrm{MT}$. Tingkat produksi optimal yang diperoleh usahatani Jagung di Kampung Tumbit Melayu Kecamatan Teluk Bayur Kabupaten Berau adalah $4.057 \mathrm{~kg} / \mathrm{ha} / \mathrm{MT}$ dalam sekali musim tanam.Besarnya 
penerimaan optimal yang diperoleh usahatani Jagung di Kampung Tumbit Melayu Kecamatan Teluk Bayur Kabupaten Berau adalah sebesarRp 14.195.443,-/ha/MT dengan biaya produksi sebesar Rp 7.819.210,-/ha/MT dan produksi optimal sebesar 4.057 $\mathrm{kg} / \mathrm{ha} / \mathrm{MT}$ adalah sebesar Rp 7.006.233,/ha dalam sekali musim tanam.Besarnya tingkat keuntungan optimal yang diperoleh usahatani Jagung di Kampung Tumbit Melayu Kecamatan Teluk Bayur Kabupaten Berau adalah sebesar 2.992 $\mathrm{kg} / \mathrm{ha} / \mathrm{MT}$, dengan penerimaan yang diperoleh sebesar Rp 10.468.813,-/ha/MT dan biaya produksi sebesar Rp 4.663.095,-/ha/MT sehingga diperoleh keuntungan sebesar Rp 5.805.718,-/ha dalam sekali musim tanam.

\section{Daftar Pustaka}

Ahyari, A. 1981.Manajemen Produksi dan Pengendalian Produksi. LPUGM, Yogyakarta.

Badan Pusat Statistik. 2018. Berau Dalam Angka 2018.

Boediono. 2002. Pengantar Ekonomi Mikro. BPFE, Yogyakarta.

Dinas Pertanian dan Peternakan. 2019. Hasil Produksi Jagung. Kabupaten Berau.

Gespersz. U. 2001. Ekonomi Manajerial Pembuatan Keputusan Bisnis. PT. Gramedia Pustaka Utama, Jakarta

Herlina, N. \& Fitriani,W. 2017. Pengaruh Prensentasi Pemangkasan Daun dan Bunga Jantan terhadap Hasil Jagung (Zea mays L).Jurnal Biodjati 2 (2) 2017.Hal 116.

Herawati N, Sasana H. 2013. Analisis Pengaruh Pendidikan, Upah Pengalaman Kerja, Jenis Kelamin Dan Umur Terhadap Produktivitas Tenaga Kerja Industri Shutllecock Kota Tegal [Diponegoro Journal Of Economics] Vol. 2. No. $4: 1-8$

Kementrian Pertanian 2013. Kinerja Sektor Pertanian 2013 Kementerian
Pertanian,

Jakarta.

http://www.deptan.go.id.

Kementerian Pertanian 2018.Kinerja

Sektor Pertanian 2018.

Kementerian Pertanian, Jakarta.

http://www.deptan.go.id.

Mubyarto. 1995. Pengantar Ekonomi

Pertanian. PT. Pustaka LP3ES, Jakarta.

Purba, Edison, 2011. Intergrated Weed Management Pada Tanaman Biotek Resisten-Herbisida. Makalah pada seminar Lustrum XI Fakultas Pertanian bekerja sama dengan Monsanto Indonesia "Tanaman Transgenik Hasil Teknologi Canggih Rekayasa Genetik untuk Pemenuhan Kebutuhan Pangan Dunia" pada tanggal 17 November 2011.Faperta. Universitas Sumatera Utara. Medan.

Sudjana. 1992. Teknik Analisis Regresi Dan Korelasi Bagi Para Peneliti. Tarsito Edisi Ketiga. Bandung.

Suwardi dan Roy E. 2009.Efisiensi Penggunaan Pupuk N pada Jagung Komposit Menggunakan Bagan warna Daun. Jurnal Balai Penelitian Tanaman Serealia, Jakarta. [Online]

Wahyudin A, Ruminta, Nursaripah SA. 2016. Pertumbuhan Dan Hasil Tanaman Jagung (Zea Maysl.) Toleranherbisida Akibat Pemberian Berbagai Dosis Herbisida Kalium lifosatgrowth And Yield Of Herbicide Tolerant Corn (Zea Maysl.) (Due Toapplication Of Various Dosages Of Potassium Glyphosate Herbicide) .Jurnal Kultivasi Vol. 15(2) : 86-91

Wasis. 1981. Pengantar Ekonomi Perusahaan. Alumni, Bandung.

Zubachtirodin S, Nadjamuddin A. 2005. Produksi jagung melalui pendekatan pengelolaan sumberdaya dan tanaman terpadu pada lahan kering masam. Seminar Rutin Puslitbang Tanaman Pangan. Bogor (ID). 